\title{
Major Salivary Gland Cancer pNX TNM
} Finding v8

National Cancer Institute

\section{Source}

National Cancer Institute. Major Salivary Gland Cancer pNX TNM Finding v8. NCI

Thesaurus. Code C132754.

Major salivary gland cancer in which the regional lymph nodes cannot be assessed. (from AJCC 8th Ed.) 